\title{
Planted stock performance 10 years after partial cutting in west-central British Columbia
}

\author{
by M.J. Waterhouse ${ }^{1}$, E.C. Wallich², N.M. Daintith ${ }^{3}$ and H.M. Armleder ${ }^{4}$
}

\begin{abstract}
Mature lodgepole pine (Pinus contorta) forests were harvested using group selection (GS) (0.02-ha openings) and irregular group shelterwood (IGS) (0.05-ha openings) systems to maintain arboreal and terrestrial lichens in the winter range of northern woodland caribou (Rangifer tarandus caribou). Ten years after planting, lodgepole pine showed excellent survival, but were smaller in the partial cut openings compared to the clearcuts. Pine grew less in the Sub-Boreal Pine-Spruce biogeoclimatic subzone (SBPSxc) than in the Montane Spruce subzone (MSxv), and trees were smaller in the GS versus IGS treatment within the MSxv subzone. Interior spruce (Picea glauca $\times$ engelmannii) grew best in the MSxv and partial cut treatments, but was significantly affected by summer frost in the clearcuts. In an operational-scale Adaptive Management trial, openings were enlarged to $0.15 \mathrm{ha}$, and both pine and spruce showed excellent survival, minimal frost damage, and 10-year size similar to clearcut conditions. This study suggests that lodgepole pine and interior spruce can be successfully regenerated in partial cut openings with acceptable growth in gaps of 0.15 ha.
\end{abstract}

Key words: caribou, group selection, interior spruce, irregular group shelterwood, light level, lodgepole pine, Montane Spruce zone, partial harvest, soil moisture, soil temperature, Sub-Boreal Pine Spruce zone, summer frost

\section{RÉSUMÉ}

Des peuplements mûrs de pin lodgepole (Pinus contorta) ont été exploitées selon des modes de sélection par groupe (SG) (trouées de $0,02 \mathrm{ha}$ ) et de régénération par coupes progressives irrégulières (CPI) (trouées de 0,05 ha) afin de préserver les lichens arboricoles et terrestres de l'habitat hivernal du caribou des forêts nordiques (Rangifer tarandus caribou). Dix années après plantation, les semis de pin lodgepole affichaient une excellente survie, mais étaient plus petits dans les troués de coupe partielle par rapport aux coupes à blanc. Les pins se sont moins développés dans la sous-zone biogéoclimatique subboréale des pins et des épinettes (SBPxc) que dans la sous-zone de l'épinette alpine (MSxv) et les arbres étaient plus petits dans les SG que dans les CPI de la sous-zone MSxv. L'hybride d’épinette blanche et d'Engelmann (Picea_glauca $\times$ engelmannii) sest mieux développée dans la sous-zone MSxv et les trouées de coupe partielle, mais a été significativement plus affectée par le gel hâtif dans les coupes à blanc. Lors d'un essai d'aménagement adaptatif de taille opérationnelle, les trouées ont été portées à 0,15 ha et autant le pin que lépinette ont montré une excellente survie, des dégâts par le gel minimes et une taille après 10 ans similaire à ce quoon retrouve dans les coupes à blanc. Cette étude suggère que le pin lodgepole et l'hybride d'épinette blanche et d'Engelmann peuvent être régénérés avec succès par des trouées de coupe partielle tout en offrant une croissance acceptable dans des trouées de 0,15 ha.

Mots clés : caribou, sélection par groupe, hybride dépinette blanche et d'Engelmann, coupes progressives irrégulières, intensité lumineuse, pin lodgepole, zone de l'épinette alpine, coupe partielle, humidité du sol, température du sol, zone subboréale des pins et épinettes, gel hâtif

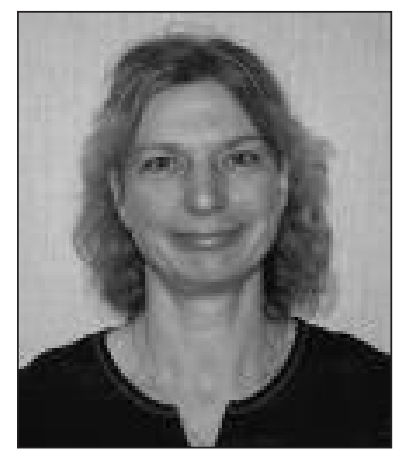

M.J. Waterhouse

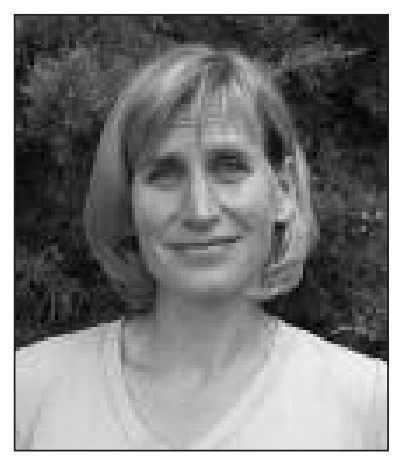

E.C. Wallich

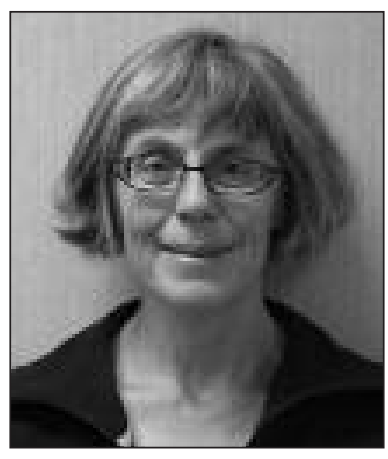

N.M. Daintith

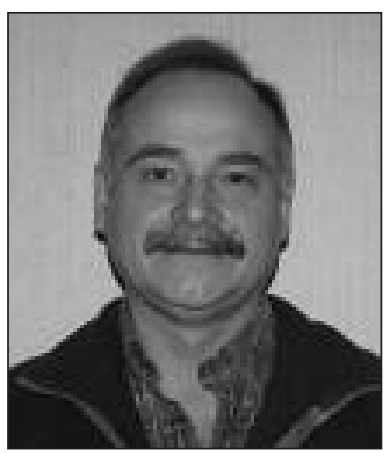

H.M. Armleder

\footnotetext{
${ }^{1}$ Silvicultural Systems Researcher, B.C. Ministry of Forests and Range, Southern Interior Region, 200-640 Borland Street, Williams Lake, British Columbia V2G 4T1. E-mail: Michaela.Waterhouse@gov.bc.ca

${ }^{2}$ Tree Physiologist, Consultant, 150 Arlayne Road, Kaleden, British Columbia V0H 1K0. E-mail: walliche@telus.net

${ }^{3}$ Silviculture Forester, B.C. Ministry of Forests and Range, Southern Interior Region, 200-640 Borland Street, Williams Lake, British Columbia V2G 4T1. E-mail: Nola.Daintith@gov.bc.ca

${ }^{4}$ Wildlife Habitat Ecologist, B.C. Ministry of Forests and Range, Southern Interior Region, 200-640 Borland Street, Williams Lake, British Columbia V2G 4T1. E-mail: Harold.Armleder@gov.bc.ca
} 


\section{Introduction}

In British Columbia, the northern woodland caribou (Rangifer tarandus caribou) (Heard and Vagt 1998) is a species of special concern due to its sensitivity to human activity (British Columbia Conservation Data Centre 2008). One of the largest herds of northern caribou (Itcha-Ilgachuz) occupies the Chilcotin plateau of west-central British Columbia (Youds et al. 2002). They are designated as threatened by the Committee on the Status of Endangered Wildlife in Canada (COSEWIC), and qualify for protection and recovery under the Canadian Species at Risk Act (SARA). In order to aid in the protection of caribou within their 1.5 million hectare range, the Cariboo-Chilcotin Land Use Plan has set aside 31\% (465 $000 \mathrm{ha}$ ) of the area for no-harvesting and parks, and a further 13\% (181 $000 \mathrm{ha}$ ) for "modified" (partial cut) forest management (Youds et al. 2002). Partial cutting means cutting or leaving selected trees within a silvicultural system to meet set objectives. The challenge in northern caribou habitat is successfully regenerating partially cut stands to meet both timber and caribou objectives.

In the Chilcotin, mature lodgepole pine forests are important caribou winter range because the forests provide an abundant and accessible source of arboreal and terrestrial forage lichens (Cichowski 1989). These stands can persist, barring fire or insect attack, for more than 300 years. Clearcut silviculture is the preferred management system for lodgepole pine, but it removes arboreal lichen-bearing trees and substantially reduces the amount of terrestrial lichen for decades. Although lodgepole pine is generally shade-intolerant, the unique ecology of the Sub-Boreal Pine-Spruce (SBPSxc) and Montane Spruce (MSxv) biogeoclimatic subzones in west-central British Columbia (Meidinger and Pojar 1991) may be conducive to forest management with partial cutting systems. The cold, dry climate and undeveloped soils support opencanopy stands with sufficiently high light levels to allow pine regeneration in the understorey.

Partial cutting, in conjunction with a group selection or shelterwood silvicultural system, is potentially advantageous because the residual forest provides arboreal lichens and shelters the terrestrial lichens in the gaps, thereby retaining large areas of high habitat value for caribou. However, a proportion of a small opening is under the influence of the adjacent mature stand, which reduces light levels and radiant energy for surface warming, and increases competition for soil moisture (Huggard and Vyse 2002a, Sagar et al. 2005, Powers et al. 2008). This effect is important for seedling regeneration because conifer growth is positively related to light level, often with maximum growth at full sunlight (Chen 1997, Wright et al. 1998, Coates and Burton 1999, Lieffers et al. 1999, Lajzerowicz et al. 2004, Vyse et al. 2006); therefore, any degree of shading is likely to slow the growth of the regenerating stand. Shading will also delay snowmelt and reduce soil temperatures (Huggard and Vyse 2002b, Lajzerowicz et al. 2004) further retarding seedling development in an environment that already has a short growing season and cold soils.

In 1995, a major research trial was established in westcentral British Columbia (Miège et al. 2001, Daintith et al. 2005) to test group selection (GS), with 0.02 -ha openings, and irregular group shelterwood (IGS), with 0.05 -ha openings, as options for "modified" harvesting in caribou habitat. The research trial also led to the development of an Adaptive Management study with larger, 0.15 -ha openings to improve the efficiency of harvesting operations and planted stock performance. These silvicultural systems are promising in terms of maintaining the lichen community (Waterhouse et al. 2009), and early results from a planted stock trial suggest that both pine and spruce can be successfully established in forest gaps with partial shade (Daintith et al. 2005). These latter results concur with Bernier (1987), Williams et al. (1999), Coates and Burton (1999), and Vyse et al. (2006) who also suggest that natural or artificial regeneration is possible in partial cut stands, especially in drier ecosystems.

This paper focusses on 10-year results from the original research and Adaptive Management trials. Specific questions include:

1. Have survival and growth rates changed from the fifthyear measurement?

2. Does biogeoclimatic subzone affect survival and growth in the partial cut treatments?

3. How does tree survival and growth reflect differences in light levels, soil temperature, and moisture availability?

4. How do the study results compare to those from a 10-yearold Adaptive Management trial where the openings were increased to 0.15 -ha openings within GS and IGS shelterwood systems?

\section{Methods}

\section{Study area}

The study area was located about $110 \mathrm{~km}$ northwest of Alexis Creek, B.C. on a gently rolling, high-elevation plateau $\left(52^{\circ} 28^{\prime} \mathrm{N}, 124^{\circ} 43^{\prime} \mathrm{E}\right)$. The five study sites of the replicated trial were established in the very dry, cold Sub-Boreal Pine-Spruce (SBPSxc) and very dry, very cold Montane Spruce (MSxv) biogeoclimatic subzones (Steen and Coupé 1997). In both subzones, lodgepole pine is the dominant tree species and undergrowth is low growing. Kinnikinnick (Arctostaphylos uva-ursi) and pinegrass (Calamagrostis rubescens) in the SBPSxc are replaced by crowberry (Empetrum nigrum), grouseberry (Vaccinium scoparium), and mosses (Pleurozium schreberi, Ptilium crista-castrensis, and Dicranum spp.) in the MSxv. A rich variety of lichens, particularly Cladonia spp. occur in both subzones. The five study sites (60-100 ha each) are spread along a $30-\mathrm{km}$ gradient that rises in elevation from $1260 \mathrm{~m}$ in the east (SBPSxc) to $1640 \mathrm{~m}$ in the west (MSxv) (Table 1). The Adaptive Management study (700 ha) was established in the same area within the MSxv subzone at an elevation of $1550 \mathrm{~m}$.

The forests at the sites were initiated after stand-destroying wildfires 220 to 300 years ago. Stands in the SBPSxc are much more open than those in the MSxv due to drier site conditions and past mortality from mountain pine beetle (Dendroctonus ponderosae). Based on 1995 cruise data, the maximum tree height was $17 \mathrm{~m}$ and gross volume was $110 \mathrm{~m}^{3} / \mathrm{ha}$ on the SBPSxc, whereas maximum tree height was $20 \mathrm{~m}$ with gross volume of $270 \mathrm{~m}^{3} /$ ha on the MSxv sites. Tree densities (trees greater than $12.5 \mathrm{~cm}$ diameter at $1.3 \mathrm{~m}$ ) ranged from about 800 stems per hectare in the SBPSxc to 1400 stems per hectare in the MSxv. A mountain pine beetle infestation in the early 1980 s killed $7 \%$ to $21 \%$ of the canopy trees, and the latest mountain pine beetle infestation killed about $4 \%$ of canopy trees by $2003,16 \%$ by 2004 , and $46 \%$ by 2006 . 
Table 1. Description of study blocks and Adaptive Management (AM) trial showing biogeoclimatic subzone, elevation, harvesting treatments, opening size (mean diameter), area cut, and transmitted light as a percentage of full sunlight in 2007.

\begin{tabular}{|c|c|c|c|c|c|c|}
\hline Block & Subzone & $\begin{array}{l}\text { Elevation } \\
\quad(\mathbf{m})\end{array}$ & Treatment & $\begin{array}{l}\text { Opening size } \\
(\mathrm{m})\end{array}$ & $\begin{array}{l}\text { Area cut } \\
(\%)\end{array}$ & $\begin{array}{c}\text { Transmitted light } \\
(\%)\end{array}$ \\
\hline \multirow[t]{3}{*}{1} & \multirow[t]{3}{*}{ SBPSxc } & \multirow[t]{3}{*}{$1280-1300$} & IGS-SO & 30 & 51 & 76 \\
\hline & & & IGS-WT & 26 & 47 & 72 \\
\hline & & & GS-SO & 15 & 33 & 61 \\
\hline \multirow[t]{3}{*}{2} & \multirow[t]{3}{*}{ SBPSxc } & \multirow[t]{3}{*}{$1310-1325$} & IGS-SO & 30 & 24 & 73 \\
\hline & & & IGS-WT & 26 & 30 & 75 \\
\hline & & & GS-SO & 13 & 24 & 73 \\
\hline \multirow[t]{3}{*}{3} & \multirow[t]{3}{*}{ MSxv } & \multirow[t]{3}{*}{$1400-1440$} & IGS-SO & 26 & 36 & 62 \\
\hline & & & IGS-WT & 25 & 35 & 68 \\
\hline & & & GS-SO & 15 & 25 & 50 \\
\hline \multirow[t]{3}{*}{4} & \multirow[t]{3}{*}{ MSxv } & \multirow[t]{3}{*}{$1475-1515$} & IGS-SO & 22 & 39 & 64 \\
\hline & & & IGS-WT & 17 & 35 & 56 \\
\hline & & & GS-SO & 14 & 25 & 53 \\
\hline \multirow[t]{3}{*}{5} & \multirow[t]{3}{*}{ MSxv } & \multirow[t]{3}{*}{$1570-1670$} & IGS-SO & 24 & 44 & 68 \\
\hline & & & IGS-WT & 22 & 46 & 57 \\
\hline & & & GS-SO & 16 & 32 & 48 \\
\hline \multirow[t]{2}{*}{$\mathrm{AM}$} & \multirow[t]{2}{*}{ MSxv } & \multirow[t]{2}{*}{1550} & IGS-SO & $30 \times 50$ & - & - \\
\hline & & & GS-SO & $30 \times 50$ & - & - \\
\hline
\end{tabular}

\section{Silvicultural systems and harvesting treatments}

In the replicated trial there are four treatments based on three silvicultural systems (irregular group shelterwood, group selection, or clearcut) and two harvesting methods (stemonly or whole-tree). The four treatments are irregular group shelterwood with stem-only harvesting (IGS-SO), irregular group shelterwood with whole-tree harvesting (IGS-WT), group selection with stem-only harvesting (GS-SO), and clearcut (CC). The two shelterwood treatments (IGS-SO and IGS-WT) created opening sizes about 1.5-2-times the average tree height, with approximately $39 \%$ of the area cut (Fig. 1, Table 1). The goal of this silvicultural system was to cut $50 \%$ of the area every 70 years. In the group selection treatment (GS-SO), openings were about one tree height and about $28 \%$ of the area was cut. This system was designed to cut $33 \%$ of the area on an 80 year cutting cycle.

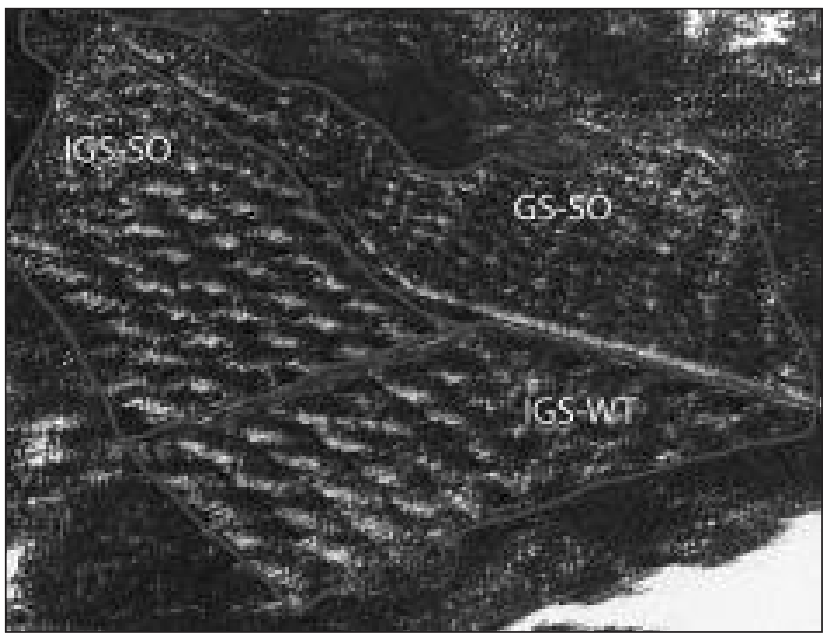

Fig. 1. Aerial view of a replicated trial block showing irregular group shelterwood system (IGS) based on 50\% area removal in 30 m openings, and group selection system (GS) based on 33\% area removal in $15 \mathrm{~m}$ openings.
For the treatments that used the stem-only harvesting method (IGS-SO and GS-SO), trees were processed in the forest then forwarded to the roadside. The remaining two treatments (IGS-WT and CC) were cut with the whole-tree method where whole trees were moved with grapple skidders for processing at the roadside. Further details on harvesting can be found in Daintith et al. (2005). All five sites were partially cut in the winter of 1996 while adjacent clearcuts were harvested within 18 months of the trial blocks.

The Adaptive Management study included two silvicultural systems, IGS-SO and GS-SO, implemented at an operational scale (Fig. 2). Prior to harvesting, a 700-ha area was stratified according to the presence of arboreal and terrestrial lichens. In March 1998, areas with high arboreal lichen abundance were harvested using the GS-SO system, whereas the IGS-SO treatment was employed in areas with predominantly terrestrial lichens. Both IGS-SO and GS-SO openings were enlarged to $30 \times 50 \mathrm{~m}(0.15 \mathrm{ha})$, and target retention levels were $67 \%$ and $50 \%$ for GS-SO and IGS-SO treatments, respectively.

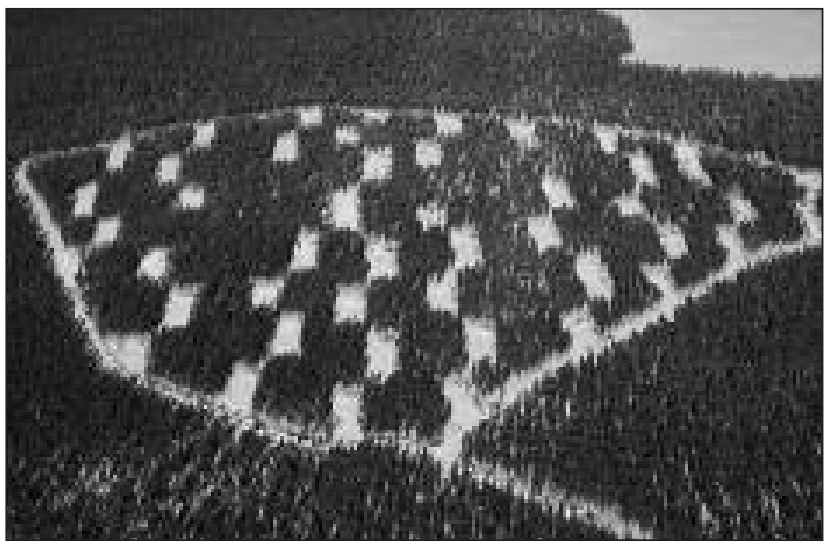

Fig. 2. Aerial view of part of the Adaptive Management trial showing the group selection (GS) silvicultural system based on 33\% area removal in $30 \times 50 \mathrm{~m}$ openings. 


\section{Layout and assessment}

In the replicated trial, each of the 5 sites were split into three approximately 15-ha treatment units, and the partial cut treatments (IGS-SO, IGS-WT, and GS-SO) were randomly assigned to the units. Nearby clearcuts of similar ecological classification were also selected at four of the five sites (no suitable clearcut was found near Site 2) (Daintith et al. 2005). From the numerous openings created by the partial cutting treatments (Fig. 1), three pairs of openings were randomly selected in the IGS-SO and IGS-WT treatment units on each site, and lodgepole pine and interior spruce were randomly assigned to openings in each pair. Forty-one seedlings were planted in each opening. In the GS-SO treatment units, five pairs of openings were randomly selected and the two species were randomly assigned to openings in each pair. Twenty-five seedlings were planted in each opening. Similar to the IGSSO and IGS-WT treatments, three plot pairs were established in the clearcuts, and lodgepole pine and interior spruce were randomly assigned to plots in each pair.

All the treatment units were planted in June 1997 with one-year-old container-grown lodgepole pine and interior spruce seedlings (Daintith et al. 2005). At the time of planting, ground-level stem diameter $(\mathrm{mm})$ and total height $(\mathrm{cm})$ were measured. Year 10 measurements included total height, leader length, ground-level diameter, and seedling condition. Seedling condition was a subjective assessment based on growth, form, and vigour; seedlings were classified as good, fair, poor, moribund, or dead. Seedlings in good or fair condition were considered to be potential crop trees. The foliage, stem, and leader of each tree were also assessed for damage and causal agents.

Within the large Adaptive Management study block, two smaller areas (one IGS-SO and one GS-SO treatment) were chosen as study locations. Four openings in each area were randomly selected then planted with a mix of one-year-old containerized lodgepole pine and interior spruce seedlings in May 1998. Total sample size for pine was 250 trees in the GS and 339 in the IGS treatments, while for spruce it was 255 in the GS and 350 in the IGS treatments. Assessment methods were identical to the replicated trial.

\section{Statistical analyses}

In the replicated trial, a mixed (random and fixed effects) model ANOVA was used to test for treatment effects on the height (10-year height, 10-year leader length, and annual height growth from 8 to 10 years) and diameter (10-year diameter and annual diameter growth from 8 to 10 years) of lodgepole pine and interior spruce. To simplify interpretation of results, separate analyses were conducted for the two species. Model effects for each species included the fixed effect of treatment and the random effects of site, site $\times$ treatment interaction, plot (nested within treatment unit and site), and tree (nested within plot, treatment, and site). Only live trees (good, fair, and poor condition) were included in the analyses. To compare responses in the SBPSxc (2 sites) and MSxv (3 sites) subzones, a second set of analyses was conducted in which the clearcut treatment was dropped and the ANOVA model was modified by adding the fixed effects of subzone and subzone $\times$ treatment interaction (random effects were as listed above with site nested within subzone).

All ANOVA models were fitted with PROC MIXED in SAS (Littell et al. 2006) where combined inter- and intra- block information were, if necessary, used to adjust for the missing clearcut at Site 2. Exact F-tests for the fixed effects were replaced by approximate (pseudo) F-tests, with the denominator degrees of freedom calculated by Satterthwaite's method (Littell et al. 2006). Least square means (and standard errors) were calculated for all groups and treatment comparisons of interest. To account for multiple comparisons, significance levels were adjusted by Scheffés method. Two a priori contrasts were also used to compare the two shelterwood treatments (IGS-SO and IGS-WT) and the two silvicultural systems using stem-only harvesting (IGS-SO and GS-SO). Results were considered significant at $\alpha=0.05$.

Seedling survival (live versus dead) and condition (good/fair versus poor) were analyzed by fitting a binary (logistic) model with fixed treatment and random site effects analogous to those described above. Model parameters were estimated and tested by the approximate maximumlikelihood method implemented in the SAS procedure GLIMMIX (Wolfinger and O'Connell 1993).

\section{Microclimate measurements in the replicated trial}

Sagar et al. (2005) measured microclimate conditions from 1997 to 2003 in the whole-tree-harvested, irregular group shelterwood treatment (IGS-WT) and the adjacent clearcut (CC) on Sites 1, 3, and 5 of the replicated trial. Additional data from 2004 to 2006 were collected from the same stations to cover the 10-year growth period. Calculations of frost, severe frost, soil temperature, soil temperature index (STI), snowfree date, total rainfall, and water stress days followed Sagar et al. (2005). In addition, soil volumetric water content $\left(\mathrm{m}^{3} / \mathrm{m}^{3}\right)$ was measured in the IGS-WT and CC treatments of the same three study sites from 1999 to 2006 . Water content reflectometers (Campbell Scientific CS615) were located at least 50 $\mathrm{m}$ from clearcut edges, and approximately $5 \mathrm{~m}$ from north edges in the IGS-WT openings. The probes were positioned 3 $\mathrm{cm}$ below the mineral/organic soil interface. In 2007, approximate light levels around study trees were estimated from below-canopy hemispherical photographs, which were taken using a fisheye lens. Photos were taken on a predetermined grid in each treatment unit, but only the photos from openings were analyzed according to Canham (1984) to derive indices of transmitted light as a percentage of full sunlight. These light measures provide a relative comparison of study blocks and treatments because beetle-killed trees have lost needles, although mortality is consistent among sites and treatments.

\section{Results}

\section{Replicated trial}

Tree survival at 10 years in the replicated trial was similar to that reported 5 years after planting (Daintith et al. 2005) with an average of $92 \%$ survival for lodgepole pine compared to $87 \%$ for interior spruce (Table 2). The harvesting treatments did not affect the average survival of either species (Table 3).

Scores of tree condition showed that $64 \%$ of the lodgepole pine were in good or fair condition (likely to become a crop tree) as compared to $57 \%$ for spruce. Lodgepole pine condition was significantly better in the clearcut compared to partial cut treatments, but not significantly different among partial cut treatments (Tables 3 and 4). In contrast, spruce condition was reduced in the clearcuts, a trend that was dramatic on most sites although statistically insignificant because of high vigour 
Table 2. Percent survival of lodgepole pine and interior spruce trees in clearcut and partial cut treatments on the five study sites and in the Adaptive Management (AM) area 10 years after planting.

\begin{tabular}{|c|c|c|c|c|c|c|c|}
\hline \multirow[b]{2}{*}{ Species } & \multirow[b]{2}{*}{ Treatment } & \multirow[b]{2}{*}{1 - SBPS } & \multicolumn{4}{|c|}{ Live trees (\%) by site and biogeoclimatic subzone } & \multirow[b]{2}{*}{$\mathbf{A M}-\mathbf{M S}$} \\
\hline & & & 2 - SBPS & $3-\mathrm{MS}$ & $4-\mathrm{MS}$ & 5 - MS & \\
\hline \multirow[t]{4}{*}{ Pine } & Clearcut & 100 & - & 99 & 88 & 88 & - \\
\hline & IGS-SO & 95 & 94 & 94 & 76 & 95 & 95 \\
\hline & IGS-WT & 94 & 94 & 99 & 84 & 96 & - \\
\hline & GS-SO & 91 & 89 & 94 & 98 & 89 & 90 \\
\hline \multirow[t]{4}{*}{ Spruce } & Clearcut & 82 & - & 95 & 90 & 60 & - \\
\hline & IGS-SO & 86 & 70 & 97 & 95 & 97 & 97 \\
\hline & IGS-WT & 87 & 85 & 95 & 98 & 89 & - \\
\hline & GS-SO & 89 & 68 & 91 & 92 & 94 & 95 \\
\hline
\end{tabular}

Table 3. Effect of harvesting treatment on average tree survival (\% live), condition (\% likely to make a crop tree), 10-year height and diameter, leader length, average annual growth from 8 to 10 years, and height-to-diameter $(H / D)$ ratio. Site was a random effect and bold probability estimates indicate significant treatment effects $(\alpha=0.05)$ on pine condition, size, and growth, and spruce $H / D$ ratio.

\begin{tabular}{|c|c|c|c|c|c|c|c|c|}
\hline \multicolumn{9}{|c|}{ Harvesting treatments ${ }^{a}$} \\
\hline Species & Variable & Clearcut & IGS-WT & IGS-SO & GS-SO & $\mathrm{DF}^{\mathbf{b}}$ & $\mathbf{F}$ & $\mathbf{p}$ \\
\hline \multirow[t]{8}{*}{ Pine } & Survival (\%) & $94^{\mathrm{a}}$ & $91^{\mathrm{a}}$ & $93^{\mathrm{a}}$ & $92^{\mathrm{a}}$ & $3,9.8$ & 0.47 & 0.71 \\
\hline & Condition (\%) & $87^{\mathrm{a}}$ & $60^{\mathrm{b}}$ & $61^{\mathrm{b}}$ & $53^{\mathrm{b}}$ & $3,10.1$ & 11.33 & $<0.01$ \\
\hline & Height $(\mathrm{cm})$ & $114^{\mathrm{a}}$ & $86^{\mathrm{ab}}$ & $88^{\mathrm{ab}}$ & $71^{\mathrm{b}}$ & $3,9.8$ & 6.30 & 0.01 \\
\hline & Leader length $(\mathrm{cm})$ & $21^{\mathrm{a}}$ & $14^{\mathrm{b}}$ & $14^{\mathrm{b}}$ & $10^{\mathrm{b}}$ & $3,10.2$ & 8.69 & $<0.01$ \\
\hline & Annual $\mathrm{H}$ growth $(\mathrm{cm})$ & $19^{\mathrm{a}}$ & $11^{\mathrm{b}}$ & $11^{\mathrm{b}}$ & $8^{\mathrm{b}}$ & $3,10.3$ & 11.70 & $<0.01$ \\
\hline & Diameter $(\mathrm{mm})$ & $29.2^{\mathrm{a}}$ & $15.6^{\mathrm{b}}$ & $15.9^{\mathrm{b}}$ & $11.5^{\mathrm{b}}$ & $3,10.4$ & 16.26 & $<0.01$ \\
\hline & Annual D growth (mm) & $4.2^{\mathrm{a}}$ & $1.9^{\mathrm{b}}$ & $1.8^{\mathrm{b}}$ & $1.1^{\mathrm{b}}$ & $3,10.7$ & 17.24 & $<0.01$ \\
\hline & $\mathrm{H} / \mathrm{D}$ ratio & $41.9^{\mathrm{c}}$ & $58.5^{\mathrm{b}}$ & $58.4^{\mathrm{b}}$ & $63.8^{\mathrm{a}}$ & $3,12.0$ & 66.49 & $<0.01$ \\
\hline \multirow[t]{8}{*}{ Spruce } & Survival (\%) & $82^{\mathrm{a}}$ & $89^{a}$ & $91^{\mathrm{a}}$ & $87^{\mathrm{a}}$ & $3,10.9$ & 1.73 & 0.22 \\
\hline & Condition (\%) & $43^{\mathrm{a}}$ & $63^{\mathrm{a}}$ & $65^{\mathrm{a}}$ & $53^{\mathrm{a}}$ & $3,9.8$ & 0.84 & 0.50 \\
\hline & Height (cm) & $56^{\mathrm{a}}$ & $82^{\mathrm{a}}$ & $84^{\mathrm{a}}$ & $64^{\mathrm{a}}$ & $3,10.8$ & 2.00 & 0.17 \\
\hline & Leader length $(\mathrm{cm})$ & $7^{\mathrm{a}}$ & $12^{\mathrm{a}}$ & $11^{\mathrm{a}}$ & $8^{a}$ & $3,10.9$ & 1.66 & 0.23 \\
\hline & Annual $\mathrm{H}$ growth $(\mathrm{cm})$ & $6^{\mathrm{a}}$ & $10^{\mathrm{a}}$ & $9^{a}$ & $6^{\mathrm{a}}$ & $3,10.9$ & 1.18 & 0.36 \\
\hline & Diameter $(\mathrm{mm})$ & $15.7^{\mathrm{a}}$ & $15.5^{\mathrm{a}}$ & $16.0^{\mathrm{a}}$ & $11.6^{\mathrm{a}}$ & $3,10.8$ & 0.98 & 0.44 \\
\hline & Annual D growth (mm) & $1.6^{\mathrm{a}}$ & $1.7^{\mathrm{a}}$ & $1.7^{\mathrm{a}}$ & $1.0^{\mathrm{a}}$ & $3,10.8$ & 0.96 & 0.44 \\
\hline & $\mathrm{H} / \mathrm{D}$ ratio & $36.5^{\mathrm{b}}$ & $52.1^{\mathrm{a}}$ & $51.7^{\mathrm{a}}$ & $54.1^{\mathrm{a}}$ & $3,10.8$ & 44.35 & $<0.01$ \\
\hline
\end{tabular}

${ }^{\mathrm{a}}$ Least square (LS) means with different letters were significantly different at $\alpha=0.05$.

${ }^{b} \mathrm{DF}=$ degrees of freedom shown as numerator degrees of freedom, followed by denominator degrees of freedom (Satterthwaite approximation).

Table 4. Condition of lodgepole pine and spruce trees shown as the percentage of good or fair trees in clearcut and partial cut treatments on each study site and in the Adaptive Management area 10 years after planting.

\begin{tabular}{|c|c|c|c|c|c|c|c|}
\hline \multirow[b]{2}{*}{ Species } & \multirow[b]{2}{*}{ Treatment } & \multirow[b]{2}{*}{1 - SBPS } & \multirow[b]{2}{*}{$2-$ SBPS } & \multicolumn{2}{|c|}{ Good or fair trees (\%) } & \multirow[b]{2}{*}{$5-\mathrm{MS}$} & \multirow[b]{2}{*}{ AM - MS } \\
\hline & & & & 3 - MS & 4 - MS & & \\
\hline \multirow[t]{4}{*}{ Pine } & Clearcut & 94 & - & 94 & 82 & 77 & - \\
\hline & IGS-SO & 66 & 33 & 69 & 52 & 81 & 80 \\
\hline & IGS-WT & 47 & 32 & 77 & 67 & 82 & - \\
\hline & GS-SO & 53 & 37 & 53 & 55 & 67 & 64 \\
\hline \multirow[t]{4}{*}{ Spruce } & Clearcut & 35 & - & 35 & 89 & 15 & - \\
\hline & IGS-SO & 47 & 8 & 77 & 89 & 93 & 92 \\
\hline & IGS-WT & 42 & 54 & 85 & 82 & 65 & - \\
\hline & GS-SO & 34 & 14 & 60 & 80 & 80 & 87 \\
\hline
\end{tabular}


in the clearcut paired with the 4 - MS site (Table 4). Pine condition was not significantly $(\alpha=0.05)$ affected by biogeoclimatic subzone (Table 5), but spruce condition was significantly depressed in the SBPSxc compared to MSxv subzone (Table 6).

The most significant damage was loss of terminal and lateral buds of interior spruce trees caused by frost. Frost damage was most evident on trees growing in clearcuts, but was also prevalent in partial cut treatments at site 2 - SBPS and in the larger gaps of site 3 - MS (Fig. 3). Frost also damaged terminal and lateral buds of pine trees growing on the SBPSxc sites and in the clearcut of site 5 - MS (highest-elevation site); however, incidence remained below $8 \%$.

Other notable damage included browsing of foliage and leaders of pine by moose (Alces alces) (about $6 \%$ of sample trees) and foliar feeding on spruce by the Cooley spruce gall adelgid (Adelges cooleyi) (about 10\% of the sample trees). Browsing by moose was most evident at site 4 - MS where about $21 \%$ of seedlings were eaten in partial cut treatments. Incidence of moose browse and frost damage was directly related to the numbers of forked stems on the MSxv sites for both pine and spruce. Adelgid damage was greatest at site 1 - SBPS (16\%) and site 3 - MS (17\%).

Most 10-year-old trees were taller than the competing vegetation. Fewer than $5 \%$ and $10 \%$ of pine and spruce, respectively, were below the competing vegetation, with the exception of spruce growing in the high-elevation, 5 - MS clearcut where approximately $24 \%$ were threatened or overtopped by the surrounding vegetation.

At 10 years, the lodgepole pine in the replicated trial averaged $90 \mathrm{~cm}$ in height with $17.7 \mathrm{~mm}$ diameter across all treatments and sites (Table 3). In the first analysis, which

Table 5. Pine condition, size, and growth as affected by biogeoclimatic subzone (fixed effect) and partial harvesting treatment. Bold probability estimates indicate significant main effects, interactions, and treatment differences within the MSxv subzone $[\alpha=0.05)$. Numerator degrees of freedom (Num. DF) apply to all responses, while denominator degrees of freedom calculated by Satterthwaite's method (Den. DF) vary with response.

\begin{tabular}{|c|c|c|c|c|c|c|c|c|c|c|}
\hline & \multicolumn{4}{|c|}{ Condition } & \multicolumn{2}{|c|}{ Height (cm) } & \multicolumn{4}{|c|}{ Annual height growth $(\mathrm{cm})$} \\
\hline & $\begin{array}{l}\text { Num. } \\
\text { DF }\end{array}$ & $\begin{array}{l}\text { Den. } \\
\text { DF }\end{array}$ & $\mathbf{F}$ & $\mathbf{P}$ & $\begin{array}{l}\text { Den. } \\
\text { DF }\end{array}$ & $\mathbf{F}$ & $\mathbf{P}$ & $\begin{array}{l}\text { Den. } \\
\text { DF }\end{array}$ & $\mathbf{F}$ & $\mathbf{P}$ \\
\hline Subzone $(Z)$ & 1 & 2 & 5.77 & 0.15 & 2.8 & 19.42 & 0.03 & 3.0 & 22.58 & 0.02 \\
\hline Treatment (T) & 2 & 40 & 1.40 & 0.26 & 39.9 & 3.56 & 0.04 & 47.0 & 6.15 & $<0.01$ \\
\hline $\mathrm{Z} \times \mathrm{T}$ & 2 & 40 & 2.77 & 0.07 & 39.9 & 4.36 & 0.02 & 47.0 & 5.42 & $<0.01$ \\
\hline IGS-SO vs. IGS-WT & - & - & - & - & - & - & - & - & - & - \\
\hline IGS-SO vs. GS-SO & - & - & - & - & - & - & - & - & - & - \\
\hline MSxv: T & - & - & - & - & 34.0 & 10.55 & $<0.01$ & 33.5 & 11.86 & $<0.01$ \\
\hline IGS-SO vs. IGS-WT & - & - & - & - & 32.4 & 1.14 & 0.29 & 32.0 & 0.34 & 0.56 \\
\hline IGS-SO vs. GS-SO & - & - & - & - & 34.8 & 9.85 & $<0.01$ & 34.2 & 13.78 & $<0.01$ \\
\hline \multirow[t]{3}{*}{ SBPSxc: T } & - & - & - & - & 19.6 & 0.33 & 0.7235 & 19.5 & 0.59 & 0.56 \\
\hline & \multicolumn{7}{|c|}{$\begin{array}{c}\text { Annual diameter } \\
\text { growth }(\mathrm{mm})\end{array}$} & \multicolumn{3}{|c|}{ Height/Diameter ratio } \\
\hline & $\begin{array}{l}\text { Num. } \\
\text { DF }\end{array}$ & $\begin{array}{l}\text { Den. } \\
\text { DF }\end{array}$ & $\mathbf{F}$ & $\mathbf{P}$ & $\begin{array}{l}\text { Den. } \\
\text { DF }\end{array}$ & F & $\mathbf{P}$ & $\begin{array}{l}\text { Den. } \\
\text { DF }\end{array}$ & $\mathbf{F}$ & $\mathbf{P}$ \\
\hline Subzone $(Z)$ & 1 & 1.2 & 11.74 & 0.14 & 3.5 & 18.83 & 0.02 & 3.9 & 2.92 & 0.16 \\
\hline Treatment (T) & 2 & 3.5 & 5.79 & 0.08 & 45.5 & 8.64 & $<0.01$ & 43.5 & 9.88 & $<0.01$ \\
\hline $\mathrm{Z} \times \mathrm{T}$ & 2 & 3.5 & 4.93 & 0.10 & 45.5 & 6.81 & $<0.01$ & 43.5 & 2.78 & 0.07 \\
\hline IGS-SO vs. IGS-WT & - & - & - & - & - & - & - & 40.9 & 0.01 & 0.94 \\
\hline IGS-SO vs. GS-SO & - & - & - & - & - & - & - & 44.8 & 14.16 & $<0.01$ \\
\hline MSxv: T & - & - & - & - & 30.8 & 16.14 & $<0.01$ & - & - & - \\
\hline IGS-SO vs. IGS-WT & - & - & - & - & 29.4 & 0.22 & 0.65 & - & - & - \\
\hline IGS-SO vs. GS-SO & - & - & - & - & 31.4 & 19.95 & $<0.01$ & - & - & - \\
\hline SBPSxc: T & - & - & - & - & 19.6 & 0.75 & 0.49 & - & - & - \\
\hline
\end{tabular}


included clearcuts and ignored subzone, 10-year diameter and annual height and diameter growth (three-year average) were significantly greater and height-to-diameter ratio significantly lower for pine growing in clearcuts compared to those in partial cut treatments (Table 3). Total height at 10 years was also greater in the clearcuts, but only significantly different from trees growing in the smallest partial cut (GS-SO) treatment.

When the data were re-analyzed with biogeoclimatic subzone included as a fixed effect, pine exhibited significant ( $\alpha=0.05)$ subzone by treatment interactions. Ten-year height, height growth, and diameter growth were significantly reduced in the GS-SO treatment compared to the IGS-SO treatment in the MSxv subzone, but not in the SBPSxc subzone (Table 5; Fig. 4). These same size variables were also significantly reduced in the SBPSxc compared to the MSxv subzone. There were no significant subzone or interactions effects for 10-year diameter or height-to-diameter ratio; however, the height-to-diameter ratio was significantly higher in the GS-SO compared to the IGS-SO treatment, regardless of subzone (Table 5).

General growth trends showed that the average annual height growth of lodgepole pine was relatively slow for the first 3 years after planting (Fig. 5). Height growth then increased in the clearcuts and in the partial cuts areas on MSxv sites; however, height growth remained relatively slow in partial cut treatments on SBPSxc sites. Annual diameter growth showed a similar pattern by site and year (data not shown).

The interior spruce trees in the replicated trial averaged $77 \mathrm{~cm}$ in height with $15.4 \mathrm{~mm}$ diameter at 10 years. In the first analysis, harvesting treatment had no significant effect on the size variables, with the exception of height-to-diameter ratio (Table 3 ). The $\mathrm{H} / \mathrm{D}$ ratio was significantly lower in the clearcuts compared to the partial cuts; however, the results were confounded by recurring frost damage to leaders and terminal buds, particularly in the clearcuts.

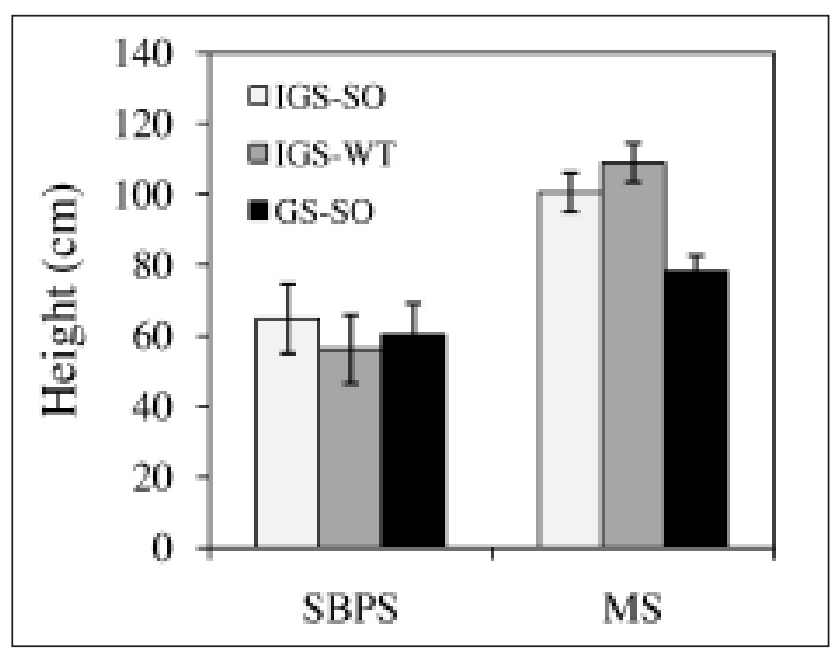

Fig. 4. Least square means and standard errors for 10-year height of lodgepole pine growing in partial cut treatments in two biogeoclimatic subzones in the study area.

Removing the clearcut treatment and adding biogeoclimatic subzone as a fixed factor showed that spruce height, diameter, and height-to-diameter ratio were significantly lower in the SBPSxc compared to the MSxv subzone (Table 6). The least square means and standard errors for height and diameter in the SBPSxc were $43 \pm 4 \mathrm{~cm}$ and $9.0 \pm 0.6 \mathrm{~mm}$, respectively, whereas height was $99 \pm 5 \mathrm{~cm}$ and diameter was $18.0 \pm 0.9 \mathrm{~mm}$ in the MSxv. Furthermore, regardless of subzone, the trees were significantly smaller in the GS-SO treatment $(60 \pm 5 \mathrm{~cm} ; 10.9 \pm .8 \mathrm{~mm})$ compared to the IGS-SO treatment $(75 \pm 5.5 \mathrm{~cm} ; 14.4 \pm .9 \mathrm{~mm})$, but of similar size among IGS-WT and IGS-SO treatments.

\section{Microclimate in the replicated trial}

Growing-season frost severe enough to cause significant tissue damage (less than $-4^{\circ} \mathrm{C}$ [Steen et al. 1990]) commonly

Table 6. Spruce condition, size, and growth as affected by biogeoclimatic subzone (fixed effect) and partial harvesting treatment. Bold probability estimates indicate significant main effects and treatment differences $(\alpha=0.05)$. Numerator degrees of freedom (Num. DF) apply to all responses, while denominator degrees of freedom calculated by Satterthwaite's method (Den. DF) vary with response.

\begin{tabular}{|c|c|c|c|c|c|c|c|c|c|c|}
\hline & \multicolumn{4}{|c|}{ Condition } & \multicolumn{3}{|c|}{ Height (cm) } & \multicolumn{3}{|c|}{ Annual height growth (cm) } \\
\hline & $\begin{array}{c}\text { Num. } \\
\text { DF }\end{array}$ & $\begin{array}{c}\text { Den. } \\
\text { DF }\end{array}$ & $\mathbf{F}$ & $\mathbf{P}$ & $\begin{array}{c}\text { Den. } \\
\text { DF }\end{array}$ & $\mathrm{F}$ & $\mathbf{P}$ & $\begin{array}{c}\text { Den. } \\
\text { DF }\end{array}$ & $\mathbf{F}$ & $\mathbf{P}$ \\
\hline Subzone (Z) & 1 & 5 & 24.97 & $<0.01$ & 10.2 & 77.92 & $<0.01$ & 12.9 & 93.64 & $<0.01$ \\
\hline Treatment (T) & 2 & 5 & 0.76 & 0.52 & 14.5 & 3.91 & 0.04 & 12.7 & 3.76 & 0.05 \\
\hline $\mathrm{Z} \times \mathrm{T}$ & 2 & 5 & 1.03 & 0.42 & 14.5 & 1.42 & 0.27 & 12.7 & 2.14 & 0.16 \\
\hline IGS-SO vs. IGS-WT & - & - & - & - & 16.4 & 0.14 & 0.71 & 14.3 & 0.02 & 0.88 \\
\hline \multirow[t]{3}{*}{ IGS-SO vs. GS-SO } & - & - & - & - & 13.9 & 4.68 & 0.05 & 12.1 & 5.84 & 0.03 \\
\hline & \multicolumn{4}{|c|}{ Diameter (mm) } & \multicolumn{3}{|c|}{ Annual diameter growth (mm) } & \multicolumn{3}{|c|}{ Height/Diameter ratio } \\
\hline & $\begin{array}{c}\text { Num. } \\
\text { DF }\end{array}$ & $\begin{array}{c}\text { Den. } \\
\text { DF }\end{array}$ & F & $\mathbf{P}$ & $\begin{array}{c}\text { Den. } \\
\text { DF }\end{array}$ & F & $\mathbf{P}$ & $\begin{array}{c}\text { Den. } \\
\text { DF }\end{array}$ & F & $\mathbf{P}$ \\
\hline Subzone (Z) & 1 & 10.5 & 73.56 & $<0.01$ & 11.4 & 67.65 & $<0.01$ & 5.1 & 42.43 & $<0.01$ \\
\hline Treat $(\mathrm{T})$ & 2 & 16.1 & 6.78 & $<0.01$ & 12.5 & 6.26 & 0.01 & 18.7 & 2.28 & 0.13 \\
\hline $\mathrm{Z} \times \mathrm{T}$ & 2 & 16.1 & 2.17 & 0.15 & 12.5 & 3.04 & 0.08 & 18.7 & 0.87 & 0.44 \\
\hline IGS-SO vs. IGS-WT & 1 & 18.9 & 0.31 & 0.58 & 15.0 & 0.07 & 0.79 & - & - & - \\
\hline IGS-SO vs. GS-SO & 1 & 15.3 & 7.77 & 0.01 & 11.8 & 8.11 & 0.01 & - & - & - \\
\hline
\end{tabular}



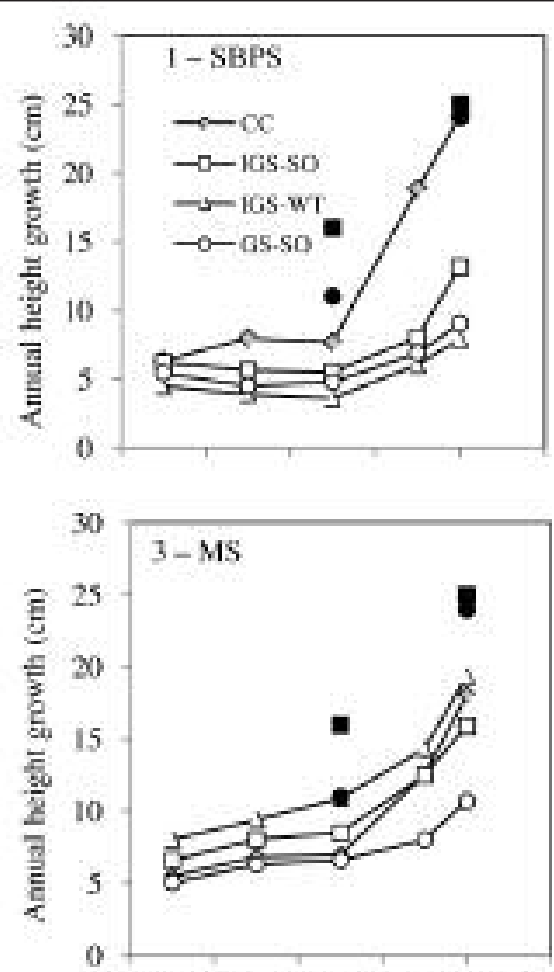

$1998 \quad 2000 \quad 2002 \quad 200420062008$
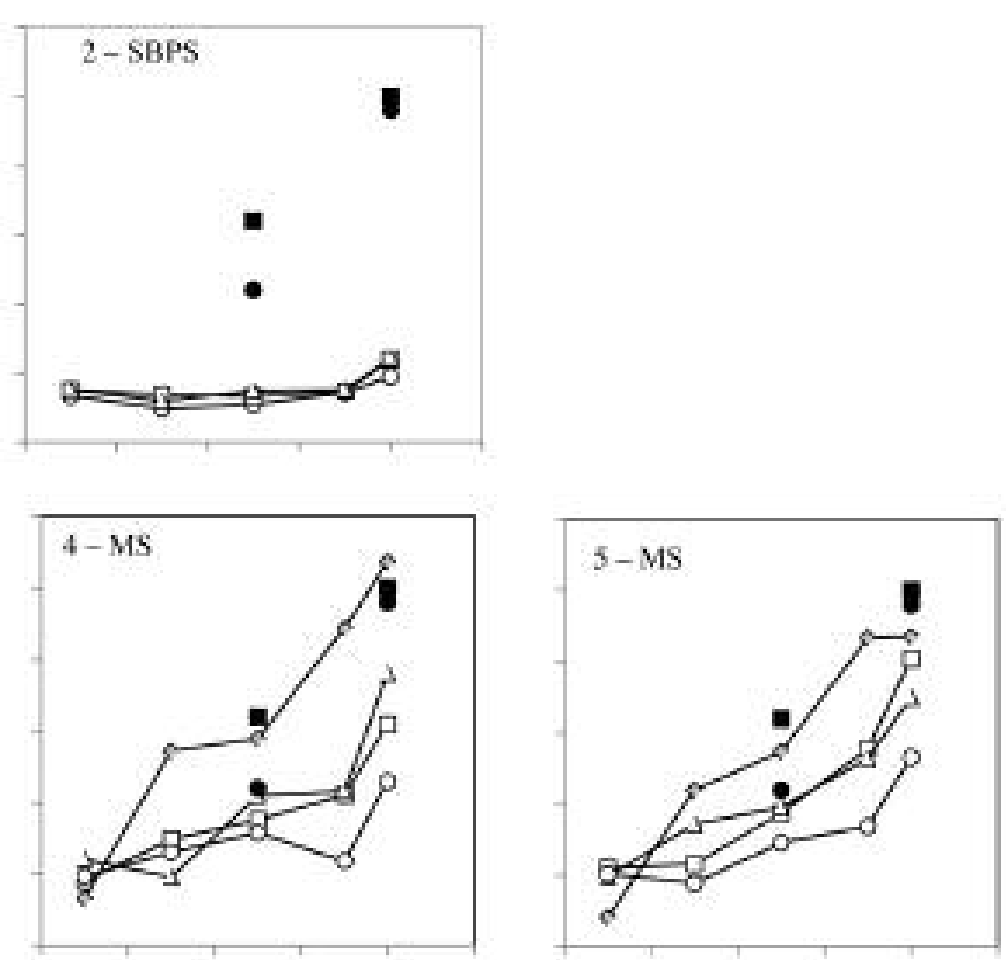

$\begin{array}{llllll}1998 & 2000 & 2002 & 2004 & 2006 & 2008\end{array}$

$19982000200022004 \quad 2006 \quad 2008$

Fig. 5. Average annual height growth of lodgepole pine trees growing in clearcut and partial cut areas on each of the study sites. Height growth in 1999 was an average of growth in 1997-2000, 2001 was an average of 2001-2002, 2003 was one year's growth, 2005 was an average of 2004-2005, and 2006 was one year's growth. As a comparison, filled black symbols show the average annual growth in the IGS-SO (square) and GS-SO (circle) treatments of the Adaptive Management trial in 2003 and 2006.

occurred in the clearcuts and less frequently in the shelterwood treatments (Table 7). A soil temperature index (STI) based on accumulated degrees above $5^{\circ} \mathrm{C}$ at the $15 \mathrm{~cm}$ soil depth provided a measure of the heat available for root growth and function, although not necessarily seedling growth and phenology (Sagar et al. 2005). STI integrated factors such as solar irradiance, near-ground air temperature, snow-free season, and soil physical properties, and showed that the clearcut soils were considerably warmer than soils in the shelterwood treatment, and that STI declined with increasing elevation. The number of moisture stress days where soil matric potential declined below -1.0 MPa showed that the lower-elevation sites were driest. Rain gauges also measured about 30\% more accumulated precipitation and later snow-free dates at the highest elevation MSxv site compared to the lowest SBPSxc site (Table 7).

Soil water content typically ranged from $0.1 \mathrm{~m}^{3} / \mathrm{m}^{3}$ to $0.3 \mathrm{~m}^{3} / \mathrm{m}^{3}$ for much of the growing season. For the first few years following harvesting, soil water content was about 0.02 $\mathrm{m}^{3} / \mathrm{m}^{3}$ to $0.05 \mathrm{~m}^{3} / \mathrm{m}^{3}$ higher in clearcuts compared to the north edges of the IGS-WT treatment (Fig. 6). This difference began to decline after 2002 at site 5 - MS and 2003 at sites 1SBPS and 3 - MS, which corresponds to the timing of mature tree mortality from the mountain pine beetle outbreak.

The results showed that light levels were higher in openings of the SBPSxc compared to the MSxv subzone, and higher in the larger IGS versus GS treatment areas (Table 1).
However, light levels were relatively consistent across all treatments at site 2 - SBPS paralleling the consistently low level of area harvested among treatments in this one site (Table 1).

\section{Adaptive management study}

Similar to the replicated trial, survival in the Adaptive Management trial was high, with $90 \%$ to $95 \%$ survival for pine and $95 \%$ to $97 \%$ survival for spruce trees, and little difference among partial cutting treatments (Table 2). Pine condition was slightly poorer in the GS-SO compared to the IGS-SO treatment, although overall condition of both pine and spruce was comparable or higher than that observed in the replicated trial (Table 4). Incidence of frost damage was also very low (less than 4\%) on the 10-year-old interior spruce trees (Fig. 3). However, moose had damaged about $30 \%$ of the pine trees growing in the GS-SO treatment.

Results showed relatively good growth for both pine and spruce trees. Pine in the IGS-SO treatment averaged ( \pm standard deviation) $156 \pm 56 \mathrm{~cm}$ in height and $35 \pm 13 \mathrm{~mm}$ in diameter, which was comparable to the best-growing pines in the clearcut adjacent to site 4 - MS of the replicated trial (Fig. 5). The pines were slightly smaller in the GS-SO treatment (114 $\pm 44 \mathrm{~cm}$ tall with $28 \pm 11 \mathrm{~mm}$ diameter) partly because these trees had been browsed by moose; however, the similarity in year-10 annual height growth in the two partial cut treatments suggested that tree size differences would likely diminish with time (Fig. 5). In both partial cut treat- 


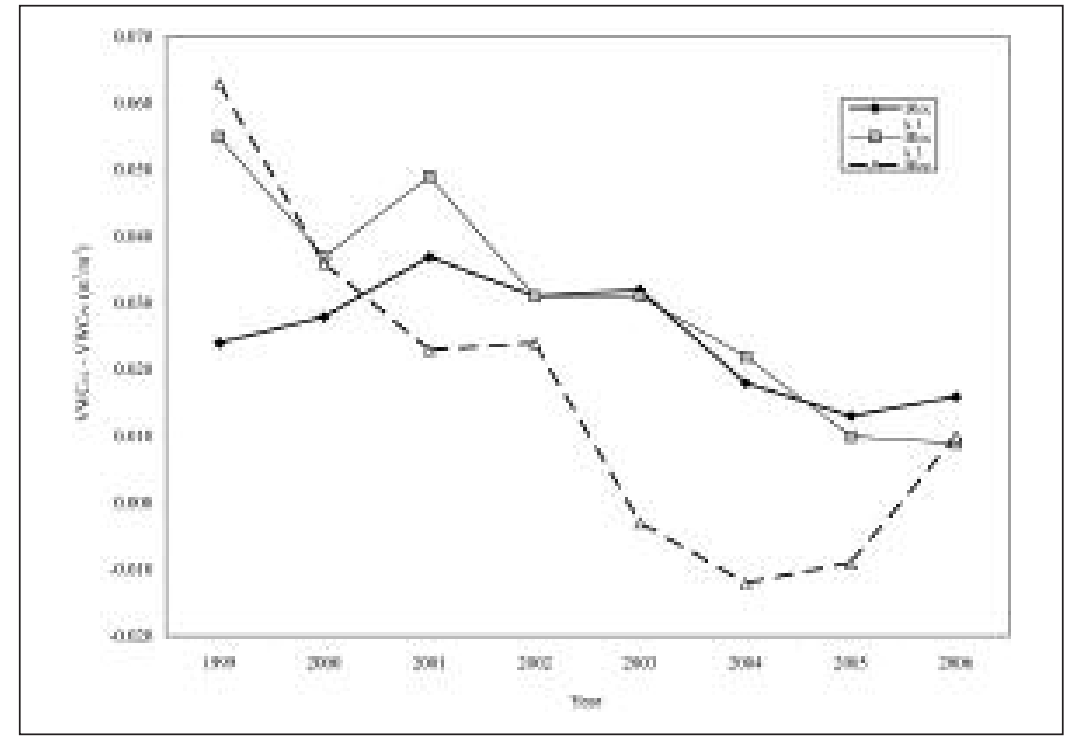

Fig. 6. Average annual difference in soil volumetric water content (VWC, m3/m3) between clearcut (CC) and IGS-WT (PC) treatments during the growing season (June 1-September 30).

ments, pine height-to-diameter ratios ( $41.7 \pm 10.6$ in GS-SO and $45.3 \pm 9.6$ in IGS-SO) were similar to ratios exhibited by pine trees growing in clearcuts.

Spruce size varied little by partial cutting treatment, and trees were larger than most others in the replicated trial. The spruce trees were $131 \pm 53 \mathrm{~cm}$ tall with an average diameter of $28 \pm 12 \mathrm{~mm}$ in the GS-SO treatment, and $146 \pm 51 \mathrm{~cm}$ tall with $30 \pm 10 \mathrm{~mm}$ diameter in the IGS-SO treatment. The low incidence of frost damage (Fig. 3) also meant that spruce height-to-diameter ratios $(49 \pm 8)$ were similar to those in partial cut treatments of the replicated trial.

\section{Discussion}

\section{Lodgepole pine response to partial cutting}

Similar to the 5-year results (Daintith et al. 2005), lodgepole pine survival was excellent 10 years after planting in clearcuts and partial cut areas on the SBPSxc and MSxv sites of the replicated trial. Also the significant pattern of reduced diameter, diameter growth, and increased height-to-diameter ratios in the partial cuts compared to the clearcuts has continued, indicating that lodgepole pine is growing under light-limited conditions (Williams et al. 1999). At year 5 , many trees were growing relatively slowly and differences among height variables were non-significant, although trees were generally shorter in the partial cuts. Annual height growth had markedly increased at eight to 10 years, with significantly greater 10-year heights in clearcuts compared to all partial cut treatments. Results from the current study were consistent with survival and growth of lodgepole pine seedlings in partial cut areas across a wide range of growing environments: from moist and cold to hot and dry (Coates and Burton 1999, Coates 2000, Vyse et al. 2006).

Light levels were higher in the partial cut treatments of the SBPSxc compared to the MSxv sites because the residual stands surrounding openings in the MSxv were relatively dense with taller trees. In addition, the smaller openings of the GS-SO treatments further reduced light levels by $10 \%$ relative to the IGS-SO treatment, with the exception of site 2 - SBPS, where light transmission was equally high despite differences in opening size. The increased shading on the MSxv sites likely accounted for the observation that tree height and annual growth were significantly better in the IGS-SO compared to GS-SO treatments on the MSxv sites, but showed no difference on the SBPSxc sites. On the other hand, transmitted light levels in all openings were greater than 45\%: the light threshold below which Vyse et al. (2006) observed a decline in lodgepole pine survival.

Another reason for the greater impact of opening size on lodgepole pine growth in the MSxv was the indirect effect of shading on air and soil temperature, and length of growing season. This study did not include measures of air temperature, but soil temperature declined with increasing elevation. Moreover, higher elevation sites had a shorter growing season because of later snowmelt. Compared to clearcut areas, the average soil temperature in the partial cut treatments was markedly cooler $\left(1.6^{\circ} \mathrm{C}\right)$ at $15 \mathrm{~cm}$ depth, and the soil temper-

Table 7. Average growing season (May 1-September 30, 1999-2007) microclimatic conditions in the clearcuts (CC) and irregular group shelterwood (IGS-WT) treatments of three of the five study sites.

\begin{tabular}{|c|c|c|c|c|c|c|}
\hline & \multicolumn{2}{|c|}{1 - SBPS } & \multicolumn{2}{|c|}{3 - MS } & \multicolumn{2}{|c|}{$5-M S$} \\
\hline & $\mathrm{CC}$ & IGS & $\mathrm{CC}$ & IGS & $\mathrm{CC}$ & IGS \\
\hline Frost: $\mathrm{T}_{\text {air }}<0^{\circ} \mathrm{C}(\text { day })^{\mathrm{a}}$ & 41 & 34 & 35 & 21 & 49 & 26 \\
\hline Severe frost: $\mathrm{T}_{\text {air }}<-4^{\circ} \mathrm{C}$ (day) & 11 & 4 & 7 & 2 & 15 & 3 \\
\hline Soil temperature at $15 \mathrm{~cm}\left({ }^{\circ} \mathrm{C}\right)^{\mathrm{b}}$ & 10.1 & 8.5 & 9.7 & 8.0 & 8.7 & 7.1 \\
\hline Soil temperature index $(\mathrm{STI})^{\mathrm{c}}$ & 808 & 593 & 770 & 537 & 641 & 438 \\
\hline Snow-free date $\mathrm{d}^{\mathrm{d}}$ & Apr 15 & Apr 26 & Apr 23 & Apr 30 & May 12 & May 10 \\
\hline Total rainfall for four years $(\mathrm{mm})^{\mathrm{e}}$ & 608 & - & 649 & - & 883 & - \\
\hline Average number of water stress days ${ }^{f}$ & 17 & 12 & 27 & 22 & 0 & 0 \\
\hline
\end{tabular}

aAir temperature measured $15 \mathrm{~cm}$ above ground (1999-2006).

bSoil temperature measured at $15 \mathrm{~cm}$ depth (1999-2006).

'Sum of the number of degrees (daily mean) over $5^{\circ} \mathrm{C}$ at $15 \mathrm{~cm}$ soil depth (1999-2006).

${ }^{\mathrm{d}}$ Based on $1 \mathrm{~cm}$ soil temperatures in the centre of clearcuts and partial cuts (1999-2006).

eTotal growing season rainfall summed over 2002-2006.

fDays when soil water potential was less than -0.10 MPa at $15 \mathrm{~cm}$ depth (1999-2007). 
ature index was about 30\% lower. Particularly at the higher elevation MSxv sites, average soil temperature was barely adequate for root growth in the partial cut areas $\left(7.1-8.0^{\circ} \mathrm{C}\right)$. Generally, root elongation is minimal until soil temperatures warm to at least $5^{\circ} \mathrm{C}$ (Lopushinsky and Max 1990), beyond which root elongation rates increase linearly with increasing soil temperature to a maximum at about $16^{\circ} \mathrm{C}$ to $20^{\circ} \mathrm{C}$ (Andersen et al. 1986).

Despite the more open canopy and higher light levels in the partial cut areas of the SBPSxc, lodgepole pine trees grew better in the higher elevation MSxv biogeoclimatic subzone. This difference was partly due to reduced precipitation at lower elevations. Lower-elevation sites were drier, and trees experienced two to three weeks of moisture stress where soil water potential declined below -1.0 MPa. Moreover, partial cutting appeared to further exacerbate these dry conditions. Soil moisture probes positioned within $5 \mathrm{~m}$ of the forest edge in partial cut areas showed that the soil was markedly drier compared to the middle of a clearcut. In other words, the live, mature trees were competing with the regenerating stand for soil moisture within at least $5 \mathrm{~m}$ of the stand edges. Differences in soil moisture converged, however, about the time that the surrounding stand was attacked and killed by the mountain pine beetle. Other studies that included direct measures of fine root density showed that the roots of mature trees extended a similar distance into openings: $5 \mathrm{~m}$ to $6 \mathrm{~m}$ for lodgepole pine growing on a dry site (Parsons et al. 1994) and throughout 0.1 ha openings on a wet ESSF site (Welke et al. 2003). Since the harvested areas in our study were relatively small with a high edge-to-open area ratio, the live, mature stand likely competed for the limited soil moisture in approximately $70 \%$ of the area in the IGS openings and $96 \%$ of the area in the GS openings. Moreover, the interaction between shade and soil moisture is important for regenerating lodgepole pine since Vyse et al. (2006) observed lower water use efficiency, or potentially greater growth reduction, for lodgepole pine grown under dry, shaded conditions.

In the Adaptive Management trial in the MSxv, openings were expanded to 0.15 ha from the original 0.05 and 0.02 ha in the IGS and GS treatments of the replicated study. These larger openings probably increased light levels, soil temperatures, and length of growing season, and reduced competition for soil moisture with the residual stand. Ten-year survival of the pine was excellent, and average height, diameter, and height-to-diameter ratios were similar to 10 -year-old pine growing in the clearcuts of the replicated trial. The effect of the larger openings was consistent with Coates (2000), who showed that growth of five-year-old lodgepole pine reached a maximum in partial cuts that were 0.1 ha or larger, although overall height and diameter remained significantly smaller than those grown in clearcuts.

\section{Interior spruce response to partial cutting}

There were no significant differences among the harvesting treatments for survival, condition, or the height and diameter variables. The increased light and moisture availability in the clearcuts that should accentuate growth was offset by recurrent summer frost damage to flushing terminal and lateral buds. Likewise, diameter growth was adversely affected by summer frost, but the damage was indirect, and resulted from the loss of photosynthetic leaf area and a reduction in photosynthetic rate.
Mild nighttime frosts temporarily reduce photosynthesis whereas severe frosts, colder than $-4^{\circ} \mathrm{C}$, can adversely affect photosynthetic rates for the remainder of the growing season (DeLucia and Smith 1987, Coates et al. 1994). Man and Lieffers (1997) demonstrated that partial cut treatments protected spruce seedlings and improved their productivity. They observed a greater depression of spring and fall photosynthesis in open-grown trees compared to trees that were grown under limited light, but were protected from cold events by a partial overstorey. Similarly, in our study, the partial overstorey reduced the frequency and severity of overnight radiant frost events. For example, in the clearcut adjacent to site 1- SBPS, nighttime temperatures during the growing season fell below $-4^{\circ} \mathrm{C}$ an average of 11 nights per year during the 10 years of the study. At least once per growing season, the nighttime temperatures dropped below $-8^{\circ} \mathrm{C}$. In contrast, in the partial cut areas, the temperature fell below $-4^{\circ} \mathrm{C}$ an average of four nights per year, and only dropped to $-8^{\circ} \mathrm{C}$ once during the 10-year study period. Therefore, the spruce trees were still damaged by frost in the partial cut areas, but the reduced frequency and severity of the events meant that the trees outgrew the frost layer sooner than those in the clearcuts. At five years, frost damaged about $37 \%$ of the spruce trees in the clearcuts but only $20 \%$ in the partial cuts. By 10 years, frost damaged fewer than $10 \%$ of spruce trees in partial cut areas compared to $50 \%$ to $60 \%$ frost-damaged trees in the clearcuts.

Spruce growth in the partial cuts in the SBPSxc biogeoclimatic subzone was significantly lower than in the MSxv possibly due to more summer frosts and less soil moisture, even though light and soil temperature were on average greater and snow-free date earlier in the SBPSxc. The significantly lower 10-year height and diameter of spruce trees in GS-SO versus IGS-SO treatments across both subzones is in response to the lower light levels in the smaller openings, and perhaps less soil moisture and lower soil temperature. In the Adaptive Management trial the spruce trees growing in 0.15-ha openings were about one-third larger with minimal frost damage than those growing in the IGS-SO MSxv treatment units in the replicated trial.

\section{Management implications}

According to the current Cariboo-Chilcotin Land Use Plan (CCLUP), 95\% of "modified" harvesting will occur in the MSxv subzone, and about $80 \%$ of the area will be managed using the irregular group shelterwood system designed for sites occupied with mostly terrestrial lichens (Youds et al. 2002). The initial harvest would remove $50 \%$ of the standing area, creating openings two tree heights in width and three to four tree heights in length. Where arboreal lichen is abundant, the CCLUP prescribed a group selection system, which removes 33\% of standing area creating openings of similar size to those of the IGS system (Youds et al. 2002). These sizes are comparable to the 0.15 ha openings created in the Adaptive Management trial.

The results from the replicated trial showed that the relatively small gaps created by the IGS and GS treatments in the MSxv were successfully regenerated with lodgepole pine and spruce. Survival was excellent although lodgepole pine height and diameter growth rates were significantly curtailed especially in the GS openings (0.02 ha). The Adaptive Management trial clearly showed that growth of both lodgepole pine and interior spruce growth could be greatly improved in the 
MSxv by simply increasing opening sizes to 0.15 ha while maintaining $50 \%$ and $67 \%$ of existing stand area for IGS and GS systems, respectively. Success of this strategy should be tested on other sites, but the fact that lodgepole pine growth rates were on par with those growing in clearcuts suggests wide applicability.

In the very dry, very cold Sub-Boreal Pine-Spruce biogeoclimatic subzone, growth of lodgepole pine was slow due to dry, cool soils. Spruce was also limited by the dry, cool soils and severely affected by summer frost damage; therefore, interior spruce is not recommended for reforesting SBPSxc sites. Currently, the CCLUP recommends conventional clearcutting as the principal harvesting system in the SBPSxc mostly due to concerns about mistletoe infection; however, IGS system could be used to harvest small areas rich in terrestrial lichen.

In terms of choosing stem-only versus whole-tree harvesting, results to date show little difference between treatments. The replicated trial showed that the two treatments had no effect on planted tree survival and growth to 10 years, although modeling of the long-term site productivity in the study area suggests that stem-only harvesting would be the best means of maintaining productivity if rotations are less than 80 years (Wei et al. 2000). Both harvesting systems also caused a similar reduction in the abundance of terrestrial lichen (Waterhouse et al. 2009); however, since increased woody debris is generally negatively related to lichen abundance, woody debris needs to be aggregated rather than dispersed if stem-only harvesting is used.

The long-term effects of partial cutting on lodgepole pine and spruce growth will never be fully realized in this study because the mountain pine beetle had killed about $59 \%$ of the trees as of 2008. However, despite the heavy pine mortality across the caribou range, the IGS and GS silvicultural systems are still the best options for maintaining caribou habitat (Armleder and Waterhouse 2008).

\section{Acknowledgements}

We gratefully acknowledge the many people who have collected data for the trial, including Amanda Nemec, who performed most of the data analysis, and Wendy Bergerud, who provided a statistical review. Also, thank you to the three anonymous reviewers of the paper. Block harvesting was done by Riverside Forest Products Ltd., Soda Creek Division in Williams Lake, B.C. Recent financial support has been through the B.C. Forest Investment Account - Forest Science and Land Base Programs and the B.C. Ministry of Forests and Range.

\section{References}

Andersen, C.P., E.I. Succoff and R.K. Dixon. 1986. Effects of root zone temperature on root initiation and elongation in red pine seedlings. Can. J. For. Res. 16: 696-700.

Armleder, H. and M. Waterhouse. 2008. Mountain pine beetle and northern caribou: The Itcha-Ilgachuz experience. In Mountain pine beetle: from lessons learned to community-based solutions. Conf. Proc. June 10-11, 2008. BC J. Ecosystems and Management 9: 102-105.

Bernier, P.Y. 1987. Regeneration and growth of lodgepole pine in small openings in the Alberta Foothills. Can. J. For. Res. 17: 758-759. British Columbia Conservation Data Centre. 2008. Conservation status report Rangifer tarandus pop.15. In B.C. Species and Ecosys- tems Explorer, v.3.3.1. B.C. Min. Environ., Victoria, BC. Available at http://a100.gov.bc.ca/pub/eswp/reports.do?index $=4$

Canham, C.D. 1984. An index for understory light levels in and around canopy gaps. Ecology 69: 1634-1638.

Chen, H.Y.H. 1997. Interspecific responses of planted seedlings to light availability in interior British Columbia: survival, growth, allometric patterns, and specific leaf area. Can. J. For. Res. 27: 1383-1393.

Cichowski, D.B. 1989. Seasonal movements, habitat use and winter feeding ecology of woodland caribou in west-central British Columbia. MSc thesis, Univ. British Columbia, Vancouver, BC.

Coates, K.D. 2000. Conifer seedling response to northern temperate forest gaps. For. Ecol. Manage. 127: 249-269.

Coates, K.D. and P.J. Burton. 1999. Growth of planted tree seedlings in response to ambient light levels in northwestern interior cedar-hemlock forests of British Columbia. Can. J. For. Res. 29: 1374-1382.

Coates, K.D., S. Haeussler, S. Lindeburgh, R. Pojar and A.J. Stock. 1994. Ecology and silviculture of interior spruce in British Columbia. For. Can. and B.C. Min. For., Victoria, BC. FRDA Report 220. $182 \mathrm{p}$.

Daintith, N.M., M.J. Waterhouse and H.M. Armleder. 2005. Seedling response following partial cutting in lodgepole pine forests on caribou winter range in west-central British Columbia. For. Chron. 81: 409-417.

DeLucia, E.H. and W.K. Smith. 1987. Air and soil temperature limitations on photosynthesis in Engelmann spruce during summer. Can. J. For. Res. 17: 527-533.

Heard, D.C. and K.L. Vagt. 1998. Caribou in British Columbia: a 1996 status report. Rangifer. Special Issue 10: 117-122.

Huggard, D.J. and A. Vyse. 2002a. Comparing clearcutting and alternatives in a high-elevation forest: early results from Sicamous Creek. Res. Br., B.C. Min. For., Victoria, BC. Exten. Note 63. 10 p.

Huggard, D.J. and A. Vyse. 2002b. Edge effects in high elevation forests at Sicamous Creek. Res. Br., B.C. Min. For., Victoria, BC. Exten. Note 63. 8 p.

Lajzerowicz, C.C., M.B. Waters, M.J. Krasowski and H.B. Massicotte. 2004. Light and temperature differentially colimit subalpine fir and Engelmann spruce seedling growth in partial-cut subalpine forests. Can. J. For. Res. 34: 249-260.

Lieffers, V.J., C. Messier, K.J. Stadt, F. Gendron and P.G. Comeau. 1999. Predicting and managing light in the understory of boreal forests. Can. J. For. Res. 29: 796-811.

Littell, R.C., G.A. Milliken, W.W. Stoup, R.D. Wolfinger and O. Schabenberger. 2006. SAS for Mixed Models, Second Edition. SAS Institute Inc., Cary, NC. 814 p.

Lopushinsky, W. and T.A. Max. 1990. Effect of soil temperature on root and shoot growth and on budburst timing in conifer seedling transplants. New For. 4: 107-124.

Man, R. and V.J. Lieffers. 1997. Seasonal photosynthetic responses to light and temperature in white spruce (Picea glauca) seedlings planted under an aspen (Populus tremuloides) canopy and in the open. Tree Physiol. 17: 437-444.

Meidinger, D. and J. Pojar. 1991. Ecosystems of British Columbia. B.C. Min. For., Victoria, BC. Spec. Rep. Ser. 6. 330 p.

Miège, D.J., T. Goward, M.J. Waterhouse and H.M. Armleder. 2001. Impact of partial cutting on lichen diversity in lodgepole pine forests on the Chilcotin Plateau of British Columbia. Res. Br., B.C. Min. For., Victoria, BC. Work. Pap. 55. 29 p.

Parsons, W.F.J., S.L. Miller and D.H. Knight. 1994. Root-gap dynamics in a lodgepole pine forest: ectomycorrhizal and nonmycorrhizal fine root activity after experimental gap formation. Can. J. For. Res. 24: 1531-1538.

Powers, M.D., K.S. Pregitzer and B.J. Palik. 2008. Physiological performance of three pine species provides evidence for gap partitioning. For. Ecol. Manage. 256: 2127-2135.

Sagar, R., M. Waterhouse and B. Chapman. 2005. Microclimate studies in silvicultural systems on the Chilcotin Plateau of British 
Columbia: the Itcha-Ilgachuz project (1997-2003). Res. Br., B.C. Min. For., Victoria, BC. Tech. Rep. 022. 29 p.

Steen, O.A. and R.A. Coupé. 1997. A field guide to forest site identification and interpretation for the Cariboo Forest Region. B.C. Min. For., Victoria, BC. Land Manage. Handb. 39.

Steen, O.A., R.J. Stathers and R.A. Coupé. 1990. Identification and management of summer frost-prone sites in the Cariboo Forest Region. B.C. Min. For., Victoria, BC. FRDA Rep. 157. 20 p.

Vyse, A., C. Ferguson, S.W. Simard, K. Tamaki and P. Puttonen. 2006. Growth of Douglas-fir, lodgepole pine, and ponderosa pine seedlings underplanted in a partially-cut, dry Douglas-fir stand in south-central British Columbia. For. Chron. 82: 723-732.

Waterhouse, M.J, H.M. Armleder and A.F.L. Nemec. 2009. Terrestrial lichen response to partial cutting in lodgepole pine forests on caribou winter range in west-central British Columbia. Unpublished manuscript on file with B.C. Ministry of Forests and Range, Williams Lake, BC.

Wei, X., W. Liu, M. Waterhouse and H. Armleder. 2000. Simulation on impacts of different management strategies on long-term site productivity of lodgepole pine forests in the central interior of British Columbia. For. Ecol. Manage. 133: 217-229.
Welke, S.E., G.D. Hope and G.A. Hunt. 2003. Effects of harvesting on fine root biomass and decomposition in an Engelmann spruce subalpine fir forest. Can. J. For. Res. 33: 847-853.

Williams, H., C. Messier and D.D. Kneeshaw. 1999. Effects of light availability and sapling size on the growth and crown morphology of understory Douglas-fir and lodgepole pine. Can. J. For. Res. 29: 222-231.

Wolfinger, R. and M. O’Connell. 1993. Generalized linear mixed models: a pseudo-likelihood approach. J. Stat. Computational Simulation 48: 233-243.

Wright, E.F., K.D. Coates, C.D. Canham and P. Bartemucci. 1998. Species variability in growth response to light across climatic regions in northwestern British Columbia. Can. J. For. Res. 28: 871-886.

Youds, J., J. Young, H. Armleder, M. Folkema, M. Pelchat, R. Hoffos, C. Bauditz and M. Lloyd. 2002. Cariboo-Chilcotin Land Use Plan: northern caribou strategy. Cariboo Mid-Coast Interagency Management Committee, Williams Lake, BC. Spec. Rep. 84 p. 